\title{
More Dutch Municipalities Decide for Environmental Friendly Post-Collection of Plastic Waste
}

\author{
Raymond Gradus* \\ School of Business and Economics and Tinbergen Institute, Vrije Universiteit Amsterdam, Netherlands
}

Submission: February 01, 2021; Published: February 08, 2021

*Corresponding author: Raymond Gradus, School of Business and Economics and Tinbergen Institute, Vrije Universiteit Amsterdam, De Boelelaan 1105, Amsterdam, The Netherlands

Abstract

In the Netherlands, much effort is made to recycle plastic waste by residents, who separate plastic waste at home. Based on evidence from the north of the Netherlands, post collection or mechanical separation can be a viable alternative as more useful plastics are separated and the number of Dutch municipalities choosing this technique increases rapidly.

Keywords: Plastic waste; Home separation, Mechanical separation

\section{Introduction}

In the Netherlands, the post collection or mechanical separation of household plastic waste (hereafter post separation) is becoming a serious alternative for source separation by households. Notably, since 2013, some municipalities in the north of the Netherlands have invested in post separation with on average more plastic waste recycled per inhabitants [1]. For these municipalities, plastics are collected with mixed waste streams and separated using infrared and film-grabber techniques in factories close to [2]. In 2019 and 2020, several municipalities as Rotterdam and Leiden followed as home-separation of plastic waste yields both in quantity as in quality disappointing results $[2,3]$. From January 1, 2021, Amsterdam, Utrecht and three other Dutch municipalities decided that plastic waste only will be separated by a machine.

Interestingly, for Rotterdam there is circumstantial evidence that the amount of plastic waste collected per inhabitant is ten times higher with post separation [2]. Moreover, post separation can have some other advantages as well. There is evidence that the quality of recycled plastic waste is better in case of post-separation than with home-separation. In [3], it is shown that post separation generates lower polymeric contamination of sorted plastics as PET, PE, PP, and other plastic streams than home separation. Due to this lower contamination, the revenues of second-hand plastics are higher. A serious problem of home separation is the low quality of separated plastic waste. In the Netherlands, still 25$30 \%$ of home separated plastic waste is burned and large parts are exported to Asia or Turkey [3]. After China closed its border in 2018, it is exported to Bangladesh, Vietnam and Indonesia with even worse waste management systems. Therefore, there is an increasing evidence that European plastic waste recycling is a pathway to ocean debris of plastic waste [4]. In addition, the costs of cleaning collection points or collecting curb side containers for plastic waste is avoided as well, although an expensive investment in a post separation machine is needed.

In cities with many apartments, where it is more difficult to store recyclables at home, it seems advisable to implement this post separation. However, even for small municipalities, postseparation has several advantages [1]. Therefore, recently, an increasing number of small- and medium-sized municipalities have changed to post separation for all inhabitants as well (see the appendix for a list of these municipalities since 2019). Some municipalities in the province Noord-Holland have a joint system with post separation for inner cities and home separation for the rest. Interestingly, in recent years the number of inhabitants without home separation of plastics increased from approximately 1 million to 3.4 million in the beginning of this year. Thus, for approximately $20 \%$ of Dutch households, plastic waste is collected with mixed waste stream. 
Nevertheless, most Dutch municipalities stick to home separation mostly in combination with unit-based pricing of waste (UBP), although the pricing of waste can have serious drawbacks such as illegal or illicit dumping or problems with bags. Circumstantial evidence in large cities such as Arnhem, where UBP was recently implemented, shows that dumping increased substantially. There is empirical evidence that not only the quality of plastic waste deteriorates but textile and biowaste due to the introduction of UBP systems [5]. Some environmental groups stress the importance of home separation as it can generate an awareness effect for shopping with less packaging material. However, unit-based pricing can also have a negative effect on the motivation of people to sort waste. There is an increasing literature showing that for some people intrinsic motivation erodes due to these price incentives. For example, in an empirical investigation of a town in the Lofoten in Norway, [6] shows that half of the inhabitants behave in that direction. In [1], the interaction effect of post separation with unit-based pricing is tested. As this effect is not significant, this gives an indication that the awareness effect of such a system on reduction of plastic waste is non-existing on average.

In [7], a cost-effectiveness analysis of the recycling of plastic waste compared with the more conventional incineration of plastic waste, using 2015 data for the Netherlands, is given. Both options have unique revenues and costs. The main benefit of plastic recycling is the avoidance of $\mathrm{CO}_{2}$ emissions that otherwise would occur during incineration and from the production of virgin plastic material. At the same time, there are significant costs involved in recycling plastic waste as compensated by the packaging industry. The benefit of plastic waste incineration is the energy that can be recovered, which reduces emissions in the regular energy production sector by displacing production. The main cost associated with incineration is the requirement for a waste-to-energy plant with the associated capital investment. In [7], calculating the costs and revenues of both plastic waste treatment options and comparing the results leads to an implicit $\mathrm{CO}_{2}$ abatement price of $€ 178 / \mathrm{t}$ of $\mathrm{CO}_{2}$ in the case of plastic recycling. The cost-effectiveness of plastic recycling-in terms of cost per tonne of $\mathrm{CO}_{2}$ reduction-is low.

This is far higher than alternatives for saving $\mathrm{CO}_{2}$, such as wind energy (€30). Therefore, if the same amount of money now paid on so-called plastic recycling is spent on wind energy six times as much greenhouse gas emissions can be saved. Although a published business case is lacking for the Netherlands, based on foreign studies it can be shown that post separation is much cheaper [2]. Consequently, the cost effectiveness of separating plastic waste will improve if post separation is chosen.

\section{Conclusion}

In the Netherlands, plastic waste recycling is high on the policy agenda. Much effort is made to recycle, mostly by residents, who separate plastic waste at home. However, much of the separated waste is of low quality and not recycled into new products. Moreover, the cost-effectiveness of plastic recycling versus incineration is very low. Based on evidence from the north of the Netherlands and recently Rotterdam, post collection or mechanical separation can be a viable alternative as more useful plastics are separated. Furthermore, there is some evidence that cost-effectiveness increases if post separation is chosen. Therefore, since 2019 the number of households with post separation increased from seven percent in 2014 to twenty percent in 2021 and there is room for further increase..

\section{References}

1. Dijkgraaf E, Gradus RHJM (2020) Post separation of plastic waste: Better for the environment and lower collection costs? Environmental Resource Economics 77: 127-142.

2. Gradus R (2020) Postcollection separation of plastic recycling and design-for-recycling as solutions to low cost-effectiveness and plastic debris. Sustainability 12(20): 8415 .

3. Brouwer M, Picuno C, Thoden van Velzen EU, Kucha K, De Meester S, et al. (2019) The impact of collection portfolio expansion on key performance indicators of the Dutch recycling system for PostConsumer Plastic Packaging Waste, a comparison between 2014 and 2017. Waste Management 100: 112-121.

4. Bishop G, Styles D, Lens PNL (2020) Recycling of European plastic is a pathway for plastic debris in the ocean. Environmental International 142: 105893.

5. CPB (2017) De Circulaire Economie Van Kunststof: Van Grondstoffen Tot Afval; CPB: Den Haag, The Netherlands.

6. Heller MH, Vatn A (2017) The divisive and disruptive effect of a weightbased waste fee. Ecological Economics 131: 275-285.

7. Gradus RHJM, Nillesen PHL, Dijkgraaf E, Koppen RJ van (2017) A costeffectiveness analysis for incineration or recycling of Dutch household plastic waste. Ecological Economics 135: 22-28.

Appendix: List of Dutch municipalities, which changed to post separation since 2019.

\begin{tabular}{|c|c|c|}
\hline Municipality & Time of Change & Inhabitants \\
\hline Leiden & 19-Jan & 124320 \\
\hline Cappele aan den IJssel & 19-Jan & 66864 \\
\hline Rotterdam & 19-Nov & 638751 \\
\hline Leiderdorp & 20-Jan & 27214 \\
\hline Oegstgeest & 20-Jan & 23889 \\
\hline Ridderkerk & 20-Jan & 45797 \\
\hline Barendrecht & 20-Jan & 48485 \\
\hline Albrandswaard & 20-Jan & 25226 \\
\hline Noord-Beveland & 20-Jan & 7313 \\
\hline Borsele & 20-Jan & 22721 \\
\hline Reimerswaal & 20-Jan & 22565 \\
\hline Terneuzen & 20-Jan & 54440 \\
\hline Amsterdam & 21-Jan & 855896 \\
\hline Utrecht & 21-Jan & 347526 \\
\hline Westerwolde & 21-Jan & 24684 \\
\hline Nieuwegein & 21-Jan & 62448 \\
\hline Bunschoten & 21-Jan & 21265 \\
\hline & & \\
\hline & & \\
\hline
\end{tabular}

${ }^{1}$ The number in 2018. 
(C) This work is licensed under Creative Commons Attribution 4.0 License

DOI:10.19080/IJESNR.2021.27.556208
Your next submission with Juniper Publishers will reach you the below assets

- Quality Editorial service

- Swift Peer Review

- Reprints availability

- E-prints Service

- Manuscript Podcast for convenient understanding

- Global attainment for your research

- Manuscript accessibility in different formats ( Pdf, E-pub, Full Text, Audio)

- Unceasing customer service

Track the below URL for one-step submission https://juniperpublishers.com/online-submission.php 